\title{
The Political Economy of Inequality at the Top in Contemporary Chile
}

\author{
Diego Sánchez-Ancochea
}

\section{Introduction}

The recent focus on top incomes at the international level (Atkinson and Piketty 2010; Piketty 2014; Piketty and Saez 2006) should help placing the spotlight on Latin America. The region has traditionally been characterised by high concentration of income and political influence of the elite (World Bank 2003). The interaction between economic and political concentration has led to periodic social conflicts and often contributed to institutional weakness. Social policy has also failed to redistribute income significantly, benefiting small segments of the population instead - as shown by Arroyo and Lindert in their contribution to this volume.

According to the historical literature, initial control over resources by a rentseeking elite led to a highly skewed development model. Although there is a debate on whether this process begun in colonial times (Acemoglu et al. 2001; Engerman and Sokoloff 1997 and earlier Furtado 1974; Cardoso and Pérez Brignoli 1979 and other authors cited in Bertola 2012) or during the late nineteenth century (Coatsworth 2008; Williamson 2010), there is no doubt of the negative consequences of inequality in the last century. The elite profited from commodity booms, often rejected progressive taxation and failed to incorporate large segments of the population into social policy. ${ }^{1}$

Given the historical relevance of top incomes and elite power, it is surprising that scholarly work on the reduction of income inequality in the last decade has ignored them, concentrating instead on short-term growth in formal employment and reduction in the skill premium (Cornia 2010). According to the most optimistic accounts,

\footnotetext{
${ }^{1}$ Following Amsden and DiCaprio (2012: 352), I define the elite as "those who enjoy privileged status and exercise decisive control over the organization of society".

D. Sánchez-Ancochea $(\square)$

University of Oxford, Oxford, UK
}

(C) The Author(s) 2017 
higher education spending increased the supply of skilled workers and reduced their relative remuneration (López-Calva and Lustig 2010). The creation of conditional cash transfers, non-contributory pensions and other social assistance programmes enhanced the redistributive capacity of the state (Cornia 2014).

What has happened with economic and political concentration at the top? Has the influence of the elite been eroded? It is likely to decrease in the future? Answering this question requires us to go beyond econometric analysis based on flawed household data available only for a few years. It also demands a more rigorous analysis of the ways top incomes are reproduced over time that goes beyond the skilled premium.

In this chapter, I consider these questions through the case of Chile-a country where the top decile has a major contribution to overall inequality (Torche 2005; Yotopoulos 1989). I draw on the recent political economy literature on institutions and elites (Acemoglu and Robinson 2012; Amsden et al. 2012; Martínez Franzoni and Sánchez-Ancochea 2013) as well as the analysis of top incomes across the world and available (quantitative and qualitative) data on Chile.

Echoing Javier Rodriguez Weber's contribution to this volume (see also Rodríguez Weber 2014), I illustrate how the Pinochet dictatorship contributed to a deepening of concentration at the top and redefined Chile's political economy. I then review studies on income distribution to show that the current share of income of the richest 1 and $10 \%$ is very high. I argue that the likelihood of a reversal of this situation in the future is limited for several reasons. ${ }^{2}$ First, market concentration is high, large business groups are powerful and production policies have changed slowly. Second, trade unions remain weak and cannot act as a countervailing force in the labour market. Third, tax reform has only increased slowly, partly due to elite opposition. At the same time, the chapter recognises Chile's gradual move towards redistributive universalism in social policy (Huber and Stephens 2012) and explores whether these policies can transform the country's political economy in the future. In the conclusion I call for more research on the elites to evaluate future distributional trajectories in Latin America. Given the lack of data and the need to consider the interactions between political, social and economic processes, future studies will need to adopt multidisciplinary approaches.

\footnotetext{
${ }^{2}$ There are also political and institutional reasons that also contribute to the persistence of inequality, including the persistent popularity of right-wing parties (who still receive $40-45 \%$ of the votes), the nature of the electoral system, the need for supermajorities to pass some important reforms and the role of the media. I thank Alan Angel for pointing out to me these factors, which will not be explored in this chapter.
} 


\section{Income Inequality and Top Incomes in Latin America}

Historically, in Latin America more resources have gone to the wealthy than anywhere else in the world. ${ }^{3}$ Although we do not have long-term data on concentration at the top, the situation in the early 1990s may constitute a good representation of earlier patterns (Table 1). ${ }^{4}$ In 1992, the richest decile in Latin America received $48 \%$ of total income, 1.7 times more than in OECD countries. ${ }^{5}$

Latin America's unique pattern of inequality becomes even clearer in Table 2, which compares income distribution in each region with the OECD. Each observation

Table 1 Various regions of the world. Income distribution by decile, 1992

\begin{tabular}{l|l|l|l|l|l}
\hline Decile & LA & Africa & Asia & Eastern Europe & OECD \\
\hline $\mathbf{1}$ & $\mathbf{1 . 6}$ & $\mathbf{2 . 1}$ & $\mathbf{2 . 6}$ & $\mathbf{2 . 2}$ & $\mathbf{2 . 5}$ \\
\hline 2 & 2.4 & 3.0 & 3.5 & 3.8 & 3.4 \\
\hline 3 & 3.0 & 3.7 & 4.8 & 5.1 & 5.3 \\
\hline 4 & 3.4 & 4.6 & 5.8 & 5.7 & 6.3 \\
\hline $\mathbf{5}$ & $\mathbf{5 . 0}$ & $\mathbf{5 . 5}$ & $\mathbf{6 . 5}$ & $\mathbf{7 . 5}$ & $\mathbf{7 . 3}$ \\
\hline 6 & 6.0 & 6.5 & 7.5 & 8.2 & 8.6 \\
\hline 7 & 7.6 & 8.6 & 9.0 & 9.4 & 10.5 \\
\hline 8 & 9.0 & 10.5 & 10.5 & 10.8 & 12.2 \\
\hline 9 & 14.0 & 13.3 & 12.4 & 12.8 & 14.8 \\
\hline $\mathbf{1 0}$ & $\mathbf{4 8 . 8}$ & $\mathbf{4 2 . 2}$ & $\mathbf{3 7 . 4}$ & $\mathbf{3 4 . 7}$ & $\mathbf{2 9 . 1}$ \\
\hline
\end{tabular}

Source: World Bank (2003)

Table 2 Various regions of the world. Income shared compared to that of the OECD, 1992

\begin{tabular}{l|l|l|l|l|l}
\hline Decile & LA & Africa & Asia & Eastern Europe & OECD \\
\hline $\mathbf{1}$ & $\mathbf{0 . 6 4}$ & $\mathbf{0 . 8 4}$ & $\mathbf{1 . 0 4}$ & $\mathbf{0 . 8 8}$ & $\mathbf{1 . 0 0}$ \\
\hline 2 & 0.71 & 0.88 & 1.03 & 1.12 & 1.00 \\
\hline 3 & 0.57 & 0.70 & 0.91 & 0.96 & 1.00 \\
\hline 4 & 0.54 & 0.73 & 0.92 & 0.90 & 1.00 \\
\hline $\mathbf{5}$ & $\mathbf{0 . 6 8}$ & $\mathbf{0 . 7 5}$ & $\mathbf{0 . 8 9}$ & $\mathbf{1 . 0 3}$ & $\mathbf{1 . 0 0}$ \\
\hline 6 & 0.70 & 0.76 & 0.87 & 0.95 & 1.00 \\
\hline 7 & 0.72 & 0.82 & 0.86 & 0.90 & 1.00 \\
\hline 8 & 0.74 & 0.86 & 0.86 & 0.89 & 1.00 \\
\hline 9 & 0.95 & 0.90 & 0.84 & 0.86 & 1.00 \\
\hline $\mathbf{1 0}$ & $\mathbf{1 . 6 8}$ & $\mathbf{1 . 4 5}$ & $\mathbf{1 . 2 9}$ & $\mathbf{1 . 1 9}$ & $\mathbf{1 . 0 0}$ \\
\hline $\mathbf{S}$ & & & & &
\end{tabular}

Source: Own calculations based on data from Table 1

\footnotetext{
${ }^{3}$ Some of the subsequent discussion borrows from Sanchez-Ancochea (2009).

${ }^{4}$ Focusing in the early 1990s is more meaningful than using more recent data because in the rest of the chapter we are precisely interested in recent changes. Ideally, we would use comparative data from the 1960s in the midst of import substitution, but this is not available.

${ }^{5}$ As we will discuss later in the chapter, using household surveys to analyse income concentration at the top is problematic. High-income groups tend to be underrepresented in many of these surveys and capital income is poorly measured. Yet comparative historical data on top-income groups in most developing countries is so far unavailable (see Piketty 2014).
} 
represents the income share of a specific decile in relation with the same share in OECD countries. For example, the poorest decile in Latin America received (in relative terms) just $64 \%$ of what the poorest decile in OECD countries earned.

In Latin America, all deciles but the top one received in 1992 a lower share of income than in any other part of the world. The situation was particularly dramatic at the bottom of the distributional structure, but the lower middle class was also affected. Latin Americans in the middle decile, for example, received just $68 \%$ of that in OECD countries (in relative terms). At the same time, the share of the richest $10 \%$ was significantly higher than in the OECD as well as Africa, Asia and Eastern Europe. The emerging literature on top incomes based on tax statistics has confirmed this problem for the 2000s. The share of the richest $1 \%$ in the Latin American countries where data is available is significantly higher than in the USA (Alvarado and Londoño 2012; Medeiros et al. 2014).

The extent of the concentration at the top is also evident when considering the distribution of wealth. Merrill Lynch in collaboration with Capgemini publishes an annual estimation of the number of high net wealth individuals (HNWI) - people who hold at least US\$ one million in financial assets (Lynch 2006). In 2006, Latin America has 300,000 HNWI (3.6\% of the world total), each of which had an average of US\$14 million in financial assets, more than four times that of rich individuals in North America or Europe (Table 3).

\subsection{Chile as a Good Example of the Regional Trend}

Chile shares with Latin America the extreme concentration at the top, something that becomes evident in Fig. 1. While the ratio of the median income to that of the poor is lower in Chile than in the USA and Israel, the Chilean top earners get more

Table 3 Number of high net wealth individuals, total wealth and average wealth per person, 2006

\begin{tabular}{l|l|c|c}
\hline Region & Number $^{\mathrm{a}}$ & Total wealth $^{\mathrm{b}}$ & Wealth per person $^{\mathrm{c}}$ \\
\hline Europe & 2.8 & 9.4 & 3.4 \\
\hline North America & 2.9 & 10.2 & 3.5 \\
\hline Asia Pacific & 2.4 & 7.6 & 3.2 \\
\hline Latin America & 0.3 & 4.2 & 14.0 \\
\hline Middle East & 0.3 & 1.2 & 4.0 \\
\hline Africa & 0.1 & 0.8 & 8.0 \\
\hline World & 8.7 & 33.3 & 3.8 \\
\hline
\end{tabular}

Source: Lynch (2006)

Notes: High net wealth individuals are defined as those with at least one million in financial assets

${ }^{a}$ Millions of people

${ }^{\mathrm{b}}$ Trillions of US\$

${ }^{\mathrm{c} M i l l i o n s}$ of US\$ 


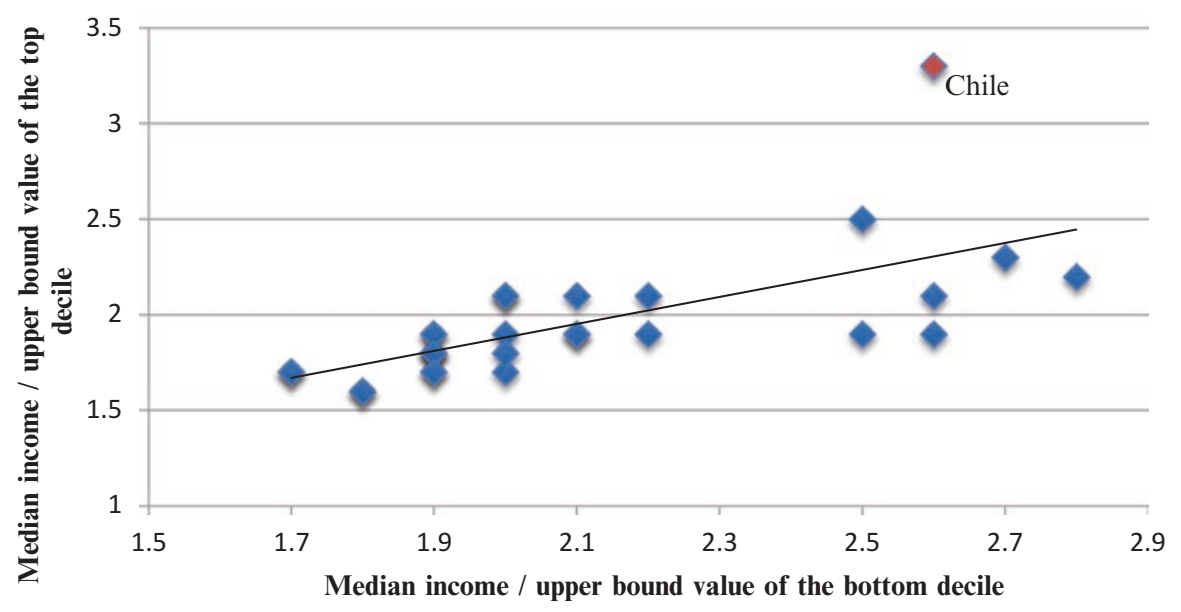

Source: own elaboration with data from OECD

Fig. 1 OECD. Income distribution, comparison of deciles, 2011. Source: Own elaboration with data from OECD

than anywhere else in the OECD. Social mobility in Chile among the bottom $90 \%$ is also high, while the opportunities to become part of the top decile are extremely low (Torche 2005). The Chilean rich have thus succeeded in protecting their social position over the long run while maintaining unique political influence (Rodríguez Fisse and Thomas 2014).

Have things changed in recent years? Has inequality gone down? For Cornia (2010: 109) Chile is a good illustration of Latin America's success at consolidating a "prudent redistribution with growth" paradigm committed to reducing the inequality inherited from the colonial past. Sandbrok et al. (2007) go as far as to place post1990 Chile as one of their four cases of social democracy in the periphery.

To evaluate the extent to which this is true, Fig. 1 presents the income share of the bottom $40 \%$, the middle $50 \%$ and the top $10 \%$ during the period 1987-2011 based on household surveys - replicating an exercise in Palma (2011). In the 1990s, Chile's income distribution changed relatively little and the top decile received around four times more than the bottom four deciles combined. Yet since 2003 there has been a gradual reversal as the income share of the top $10 \%$ decreased from 44.0 to $40.7 \%$.

Using household surveys, Friedman and Hofman (2013) argue that the income share of the top $10 \%$ actually began going down in 1990. Yet their study also shows the inconsistencies in measurements of income at the top and the difficulties to rely on household surveys to study the rich. Research based on tax information may be more satisfactory and questions the results presented in Fig. 2. Two studies are particularly useful: López et al. (2013) and Fairfield and Jorratt (2014).

Fairfield and Jorratt (2014) present the most reliable estimations and also offer a longer time spam than other studies. They benefited from access to an unpublished 


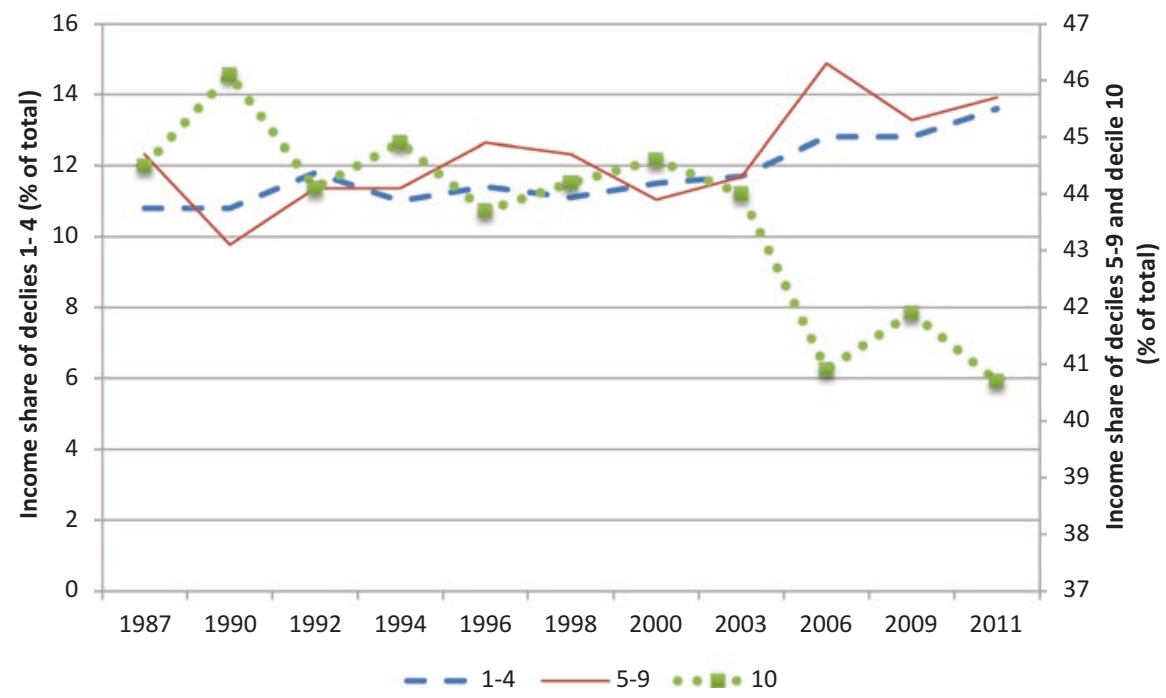

Source: own elaboration with data from SEDLAC, which comes from household surveys

Fig. 2 Distribution of household equalised income in Chile, 1987-2011, groups of deciles. Source: Own elaboration with data from SEDLAC, which comes from household surveys

database of all Chileans who paid taxes between 2005 and 2009 and used publicly available data to extend their series to 2004, 2010 and 2011. They allocate nondistributed profits to different income groups based on information from business tax returns - something that no other study has done. According to their results, the income share of the top $1 \%$ varies between $15 \%$ with no adjustments for nondistributed profits and unreported income and $33 \%$ when adjusting for profits and for tax evasion. This last number is significantly higher than the USA (18\%) - the most unequal developed country - or even Colombia. Fairfield and Jorratt (2014) do not find any clear trend for the period 2004-2011: the income level at the top shows some variance from year to year but does not go down or up overall.

López et al. (2013) rely on publicly available data, which is divided into eight different tax schedules. Their allocation of non-distributed profits is based on shaky assumptions about ownership of assets in Chile. Yet their estimations are not that different than those by Fairfield and Jorratt (2014): according to their calculations, the income level of the top $1 \%$ varies between $22 \%$ (without accounting for non-distributed profits but considering tax evasion) and $31 \%$ when all the numbers are considered. Even the lower bound estimation is higher than in South Africa, Colombia, Argentina and the USA. They also calculate the Gini coefficient adjusted by top incomes and compare it with that based on household surveys. The differences are significant: in 2010, the adjusted Gini was 0.63 and the standard Gini was 0.55 .

Two conclusions from these studies are particularly relevant for this chapter. First, despite the lack of data, it is hard to believe that distribution at the top has 
gone down significantly in the last decade. ${ }^{6}$ How much larger than $30 \%$ could the share of the top $1 \%$ have been two decades ago? Second, studies of inequality and its evolution over time cannot rely only on estimations of income distribution. Even rigorous studies like Fairfield and Jorratt (2014) are forced to make heroic assumptions and show large variation between the lower and upper bounds. If we are interested in having a full picture of economic concentration, we may need to consider multiple (qualitative and quantitative) sources, including newspaper articles on consumption and investment patterns of the rich.

\section{Top Incomes and the Political Economy of Redistribution}

Much of the economic literature on inequality has treated the top $1 \%$ like any other group, emphasising, for example, the role of human capital in determining its income. As a result, the policies proposed to reduce income concentration are the same as the ones suggested to decrease the Gini coefficient: (1) increases in the minimum wages; (2) expansion in education spending and improvement of its quality; and (3) creation of new anti-poverty social interventions (see, for example, World Bank 2003).

Yet high-income groups are different than all others in society. They are owners of the largest firms and their income depends as much on profits as on wages. When studying these groups, we must account for both the functional distribution of income and the overall process of redistribution.

In developing countries, a significant share of capital income goes to the richest groups in society. For example, in Chile, López et al. (2013) estimate that $85 \%$ of retained profits go to the top 1\%. Four-fifths of the income received by the $0.01 \%$ richest Chileans actually come from capital earnings (Fairfield and Jorratt 2014). Many factors shape the functional distribution, but two are particularly important: the level of market concentration and the strength of trade unions. Market concentration partly depends on the strength of family conglomerates, which have traditionally controlled a larger share of the economy in developing than in developed countries (Amsden 2001; Fernández Jilberto and Hogenboom 2007; Schneider 2013). Market concentration also depends on the number of firms per sector and on the productivity gap between large and small firms. Strong trade unions will also reduce the capital share.

By promoting collective bargaining, trade unions can additionally contribute to lower wage dispersion (Bhattacherjee 1987). This is most likely to happen when bargaining is centralised across the whole economy (Aidt and Tzannatos 2002). The distribution of wages also depends on the skill premium-i.e. the wage gap between skilled and unskilled workers. The skill premium is driven by the level of

\footnotetext{
${ }^{6}$ These findings coincide with recent research in other Latin American countries based on tax information and following the methodology proposed by Atkinson, Piketty and Saez; see, in particular, the work on Medeiros et al. (2014) for the case of Brazil.
} 
education - which shapes labour supply - and the productive structure of the economy - which determines labour demand. While the skill premium has received ample attention in the recent literature on inequality in Latin America (López-Calva and Lustig 2010; Gasparini et al, 2011; Gindling and Trejos 2013), it may actually be less important to explain top incomes than some of the other variables.

Finally, we should consider the redistribution of income, which depends on taxes and government spending. Some social policies redistribute in favour of the poor without eroding the income share of the wealthy. This is, for example, the case of conditional cash transfers, which given their small size do not usually demand tax increases. Universal policies, on the contrary, are more likely to create pressures towards higher taxation, thus exerting a more powerful downward pressure on top incomes (Martínez Franzoni and Sánchez-Ancochea in press).

Political forces and struggles influence the functional distribution of income, wage distribution and fiscal policy. The way markets are regulated, incentives to large firms are set, trade unions are treated and tax and social policies are designed depend directly on the strength of different actors. Unfortunately in all these areas, the economic elite usually have more influence than others. The elite play a central role in shaping political institutions and policies (Robinson 2012). In Shamus Kahn's words, "although elites are not representative of society, the distribution of power in their favor often means that elites are the engines of inequality" (Kahn 2012: 362).

The rest of this chapter explores the key factors shaping the distribution of income at the top in Chile today. I am not only interested in the situation at a point in time (e.g. how redistributive policies are in a certain year) but also in the political processes that different policies may trigger (Martínez Franzoni and SánchezAncochea 2016). To undertake this analysis, it is important to first understand the "regressive revolution" that took place in the 1970s.

\section{The Pinochet Years: A "Successful" Redistribution Towards the Top}

During the 1950s and 1960s, the improvements in income distribution-clearly illustrated in Rodriguez Weber's contribution to this book - went hand in hand with an erosion of the power of the elite. The political system moved to the left and new social groups acted as countervailing forces (Pinto 1970). ${ }^{7}$

\footnotetext{
${ }^{7}$ The significance of the political changes but also its limitations are clear when one considers social policy. During the 1950s and 1960s, social programmes in health, pensions and education expanded rapidly and by the early 1970 s social security covered $75 \%$ of the economically active population (Huber and Stephens 2012). The growing in social spending led to higher social security contributions and a larger tax burden. Yet these policies were highly segmented, primarily favouring some groups within the middle class. Social insurance involved more than ten different funds with entitlements and obligations contained in more than 2000 legal texts (Mesa-Lago 1978; Segura-Ubiergo 2007).
} 
Yet all the advances quickly reversed after the 1973 coup d'état, which was enthusiastically supported by large segments of the elite (Palma 2011). Pinochet's dictatorship triggered a return to an elite-based political economy model (Silva 1996) and led to a process of economic concentration. The redistribution of income towards the top was extraordinary - even larger than the one the USA has experienced in the last three decades. Between 1973 and 1989 the income share of the top $10 \%$ increased by $50 \%$ while that of the bottom $70 \%$ decreased by more than $35 \%$ (Palma 2011; see also Ricardo 2010).

The coup affected all the channels of economic and political concentration that we have previously discussed. First, capital concentration increased significantly, particularly as a result of the processes of privatisation. Of the 500 companies in public hands in the early 1970 s, 481 were transferred to a small number of players within the private sector. Privatisation together with the allocation of credit to a few business groups "increased the size concentration of firms and further enhanced the economic power of the 20 or so major industrial and banking groups" (Yotopoulos 1989: 696). By 1978, Chile's five most powerful conglomerates controlled $60 \%$ of the assets of the 100 largest firms, compared to $46.5 \%$ in 1969.

Second, trade unions were systematically persecuted and changes in the regulation of the labour market expanded outsourcing and free wage setting (Berg 2006). The weakening of trade unions contributed to a reduction in overall wages and eliminated a significant progressive political force. In contrast, the influence of large business groups in policymaking grew significantly during this period (Rodríguez Fisse and Thomas 2014).

Third, the capacity of the state to redistribute income weakened. Collective pensions were replaced by individual capitalisation pensions managed by private companies. All the redistributive components of the system were eliminated and pensions became exclusively linked to the financial returns on contributions (Riesco 2007). Public healthcare survived, but private providers grew significantly. A large share of health costs was passed to individuals (through private insurance contributions and copayments) and the share of public spending in the total decreased from 38 to $21 \%$ (Gogna 2004). At the same time, the taxes paid by high-income groups compared to those paid by the middle class decreased significantly, thus reducing the contribution of the wealthy towards redistribution. According to calculations by Arroyo Abad and Lindert presented elsewhere in this volume, the net benefit from social spending minus taxes received by the top quintile increased from a negative number in 1973 to more than three percentage points of GDP in the mid-1980s.

\section{Chile Since 1990: Why No More Advances?}

If we accept that top incomes have remained stable after the return of democracysomething more evident in the tax data than in household surveys - how can we explain it? In which areas has Chile experienced advances and where have things stayed the same? In this section I review some of the channels discussed in Sect. 3. 


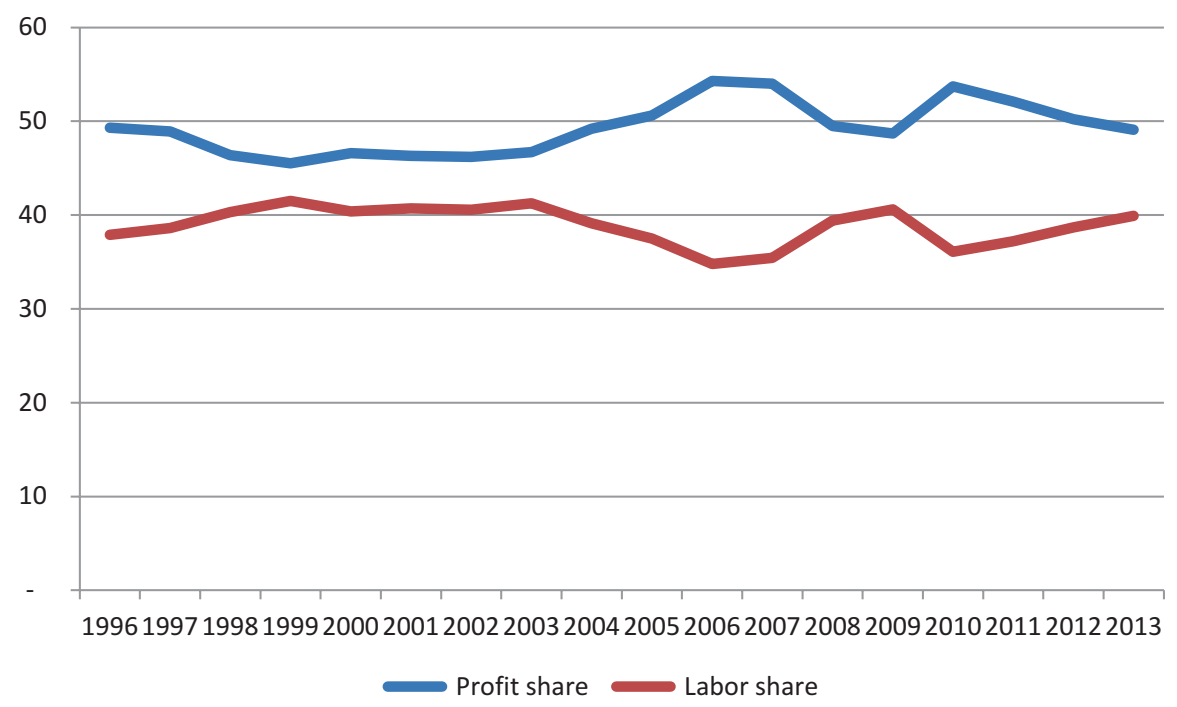

Source: own elaboration from National Income Accounts, Central Bank webpage

Fig. 3 Labor and capital share, \% GDP, 1996-2013. Source: Own elaboration from National Income Accounts, Central Bank webpage

I show that the concentration of economic power has not changed and public policy has not paid enough attention to the reduction of productivity gaps. Trade unions also remain weak and cannot act as an influential national force. In contrast, some reforms have made social policy more redistributive and could trigger progressive political trajectories in the long run. The key unanswered question is not whether Chile is still unequal, but whether these new opportunities can truly modify the political economy of inequality in the future.

\subsection{The Capital Share and Market Concentration}

During the last two decades, the capital share in GDP has remained relatively stable (Fig. 3). It increased by nine percentage points between 1999 and 2006, but has then gone back to its 1996 level. Guerreiro (2012) confirms these general patterns in a global study that corrects for the level of self-employment. She also shows that recent stability has come after large swings in previous decades, in favour of capital during the Pinochet years and against after the return to democracy. ${ }^{8}$ Chile's performance in this area is in line with global trends and consistent with many

\footnotetext{
${ }^{8}$ Studying the evolution of the capital and labour shares leads us to question the dominant discourse on the recent improvement in income distribution in Latin America. For example, according to CEDLAS data based on household surveys, Peru's Gini coefficient went down from 0.52 in
} 
other countries where capital concentration and income inequality have increased simultaneously (Karabarbounis and Neiman 2013; Piketty 2014).

Data on market concentration is patchier and does not allow us to explore changes over time systematically. Additionally, some of the best qualitative studies on business groups and economic concentration rely on data from the 1990s, thus limiting what we can say about the last decade. Nevertheless, there is enough empirical evidence to believe that concentration has not decreased significantly and remains high. ${ }^{9}$

Three conglomerates have been particularly prominent: Luksic, Angelini and Matte. In the late 1990s, these three groups alone owned all Chilean publicly traded companies with market value over 600,000 million pesos. In the last decade, large family groups have succeeded in adapting to changing global conditions by creating new ties to transnational corporations, expanding into nontradable sectors like commerce and diversifying into many different sectors (Fazio 1999; Schneider 2008).

For example, through different holdings like Quiñenco or Madeco, Luksic participates in manufacturing activities like copper and aluminium, fibre optics and flexible packaging as well as beer, wine and sodas. Luksic has also created strategic alliances in other sectors, including banking, telecommunication, electricity and tourism (Fazio 1999). The group Matte has built a diversified portfolio that includes the largest paper factory in South America together with participation in more than 30 firms in finance, mining, health, telecommunications energy, ports and others.

To explore the links between market concentration and the highest incomes, I consider the 2015 Forbes list of world billionaires. Although this kind of list only provides limited information on a few prominent families, it is still helpful to understand economic concentration. In 2015 there were ten Chileans on the Forbes list, although several were part of the same families (Table 4). Together these ten individuals have an estimated wealth of US\$34.5 billion, equivalent to $12 \%$ of Chile's GDP. Table 4 also highlights the extent to which a small number of business groups are present in multiple sectors and own a large number of companies. The top Chilean groups control most retail operations - a sector that expanded by an average annual rate of $8.2 \%$ between 2007 and 2011 - and have a strong presence in media, banking, mining and manufacturing. ${ }^{10}$

Concentration is also high at the sectoral level. In hardware stores, two companies (Easy and Sodimac) have become dominant players, contributing to the disappearance of almost 3500 companies that operated in the sector in the 1990s. Three pharmaceutical chains (Cruz Verde, Salcobrand and FASA) are responsible for more than $90 \%$ of sales. The list of sectors dominated by just two or three companies - many

\footnotetext{
2003 to 0.43 in 2013. Yet this happened at the time when the wage share decreased by more than a third according to Guerreiro (2012)'s estimations.

${ }^{9}$ For a discussion of the persistence of business groups and its economic influence in Chile and other Latin American countries, see Schneider (2008).

${ }^{10} \mathrm{http} / / / \mathrm{www}$. bloomberg.com/news/articles/2013-01-15/falabella-billionaires-surface-with-lowprofile-fortune (last accessed 7 May 2015).
} 
Table 4 Main Chilean family groups, Forbes billionaire list, 2015

\begin{tabular}{|c|c|c|c|c|c|}
\hline Name & $\begin{array}{l}\text { Estimated } \\
\text { wealth }^{\mathrm{a}}\end{array}$ & Group & $\begin{array}{l}\text { Year of } \\
\text { creation }\end{array}$ & $\begin{array}{l}\text { Some companies } \\
\text { (full or part } \\
\text { ownership) }\end{array}$ & Sectors \\
\hline $\begin{array}{l}\text { Iris } \\
\text { Fontbona }\end{array}$ & 13.5 & Luksic & $1950 \mathrm{~s}$ & $\begin{array}{l}\text { Antofagasta, } \\
\text { conglomerate } \\
\text { Quinenco }\end{array}$ & $\begin{array}{l}\text { Mining, beverages, } \\
\text { banking, } \\
\text { manufacturing, } \\
\text { energy, transportation } \\
\text { and ports }\end{array}$ \\
\hline $\begin{array}{l}\text { Horst } \\
\text { Paulmann }\end{array}$ & 4.4 & Cencosud & $1970 \mathrm{~s}$ & $\begin{array}{l}\text { Jumbo, Santa Isabel, } \\
\text { Disco, Vea, Easy, } \\
\text { Banco Paris }\end{array}$ & $\begin{array}{l}\text { Department stores, } \\
\text { supermarkets, home } \\
\text { improvement stores, } \\
\text { banking, shopping } \\
\text { malls }\end{array}$ \\
\hline $\begin{array}{l}\text { Matte } \\
\text { (Elidoro, } \\
\text { Patricia and } \\
\text { Bernardo) }\end{array}$ & 2.8 & Matte & $\begin{array}{l}\text { 19th } \\
\text { century }\end{array}$ & $\begin{array}{l}\text { CMPC, Banco Bice, } \\
\text { Entel, Colbun }\end{array}$ & $\begin{array}{l}\text { Paper, telecom, } \\
\text { banking, shipping }\end{array}$ \\
\hline $\begin{array}{l}\text { Sebastian } \\
\text { Piñera }\end{array}$ & 2.5 & LAN & 1970s & $\begin{array}{l}\text { Formerly owned } \\
\text { LAN and Chilevision }\end{array}$ & Airline, media, sports \\
\hline $\begin{array}{l}\text { Alvaro } \\
\text { Saieh } \\
\text { Bendeck }\end{array}$ & 2.5 & Corp & $1990 \mathrm{~s}$ & $\begin{array}{l}\text { Corpbanca, Copesa, } \\
\text { Unimarc, SMU, } \\
\text { Unimarc, } \\
\text { Telemercados, } \\
\text { Construmart, La } \\
\text { Tercera }\end{array}$ & $\begin{array}{l}\text { Banking, hotels, } \\
\text { supermarket } \\
\text { insurance, media }\end{array}$ \\
\hline $\begin{array}{l}\text { María Luisa } \\
\text { Solari } \\
\text { Falabella } \\
\text { and family }\end{array}$ & 2.4 & $\begin{array}{l}\text { SACI } \\
\text { Falabella }\end{array}$ & $\begin{array}{l}19 \text { th } \\
\text { century }\end{array}$ & $\begin{array}{l}\text { Falabella, Viveros, } \\
\text { Enaex, Las Condes } \\
\text { clinic }\end{array}$ & $\begin{array}{l}\text { Department stores, } \\
\text { supermarket, home } \\
\text { improvement, } \\
\text { banking and interests } \\
\text { in many other sectors }\end{array}$ \\
\hline Julio Ponce & 2.1 & SQM & $1980 \mathrm{~s}$ & $\begin{array}{l}\text { Chemical and } \\
\text { Mining Society of } \\
\text { Chile }\end{array}$ & $\begin{array}{l}\text { Fertilisers, lithium, } \\
\text { iodine, finance }\end{array}$ \\
\hline $\begin{array}{l}\text { Angelini } \\
\text { Rossi } \\
\text { (Roberto } \\
\text { and Patricia) }\end{array}$ & 2.9 & Angelini & $1950 \mathrm{~s}$ & $\begin{array}{l}\text { Holding Antarchile, } \\
\text { Arauco }\end{array}$ & $\begin{array}{l}\text { Fuel distribution, } \\
\text { fishing, shipping, } \\
\text { energy, forestry }\end{array}$ \\
\hline $\begin{array}{l}\text { Luis } \\
\text { Enrique } \\
\text { Yarur }\end{array}$ & 1.2 & Yarur & $1930 \mathrm{~s}$ & $\begin{array}{l}\text { Bank BCI, City } \\
\text { National Bank of } \\
\text { Florida, Salcobrand }\end{array}$ & $\begin{array}{l}\text { Banking, pharmacy, } \\
\text { other retail }\end{array}$ \\
\hline
\end{tabular}

an US\$ billion, valuation as 6 May 2015 Sebastian Piñera had to sell all his interests when he became president of Chile

Source: www.forbes.com and various web pages for information on groups

of which are part of larger conglomerates-also includes telecommunications (mobile and Internet), cable, supermarkets and electricity (Ruiz and Boccardo 2010; Fazio 1999).

Additionally, in the mid-2000s just five groups owned directly or indirectly almost half of all shares of the companies in Santiago's stock exchange (Solimano 2009). 
In 2007, the three largest companies (administradoras de fondos de pensiones, AFPs) controlled $74 \%$ of all pension funds in the country. Solimano also calculates an index of economic concentration for six sectors (pharmaceuticals, forestry, banking, pension funds, mining and healthcare), showing an increase in four of them during the 2000s.

\subsection{Structural Heterogeneity and Production Policies}

Like other Latin American countries, Chile has been characterised by large productivity gaps. Data in Infante and Sunkel (2009) for 2003 finds differences in employment and productivity in two different axes: between sectors and between small and large firms. Large firms are more productive than small and medium firms in all economic sectors. Also, mining, utilities and financial services are more productive than agriculture and community services - although productivity gaps by sector are lower than by size. As a result, the difference between a large mining company and a small agricultural producer is astonishing: the former is almost 40 times more productive than the latter. Most employment is located in low-productivity sectors and, as a result, is of low quality (Velasco and Huneeus 2011).

Between 1990 and 2005, successive governments of the Concertación (an alliance of centre and left-wing parties that have fought against Pinochet) did little to tackle dependence on natural resources and promote productivity diffusion to other sectors. The dominance of market-friendly ideas made state-led interventions particularly difficult (Palma 2011). Things partly changed in 2005 when a new royalty on copper, mining and other natural resources was created. The royalty taxed net profits from natural resource activities with a rate of up to $5 \%$, which can be deducted from taxable income coming from other taxes. Although Chile still has one of the lowest royalty levels in the world-it represents less than $2 \%$ of profits and $0.6 \%$ of the value of sales (López and Miller 2008) - the new tax infused the government with welcomed new resources.

The royalties were earmarked for innovation and the promotion of new sectors and funded the creation of the National Council for Innovation and Competitiveness (Consejo Nacional de Innovación para la Competitividad, CNIC). ${ }^{11}$ The initial design of the CNIC was prepared at the request of the Concertación senators Alejandro Foxley and Edgardo Boeninger and borrowed on the experiences of Australia, New Zealand, Finland and Ireland. Its creation was a top-down bureaucratic initiative: although the CNIC incorporated members from business associations to its board, the private sector's involvement and commitment to the project were quite small.

Soon after its creation, the CNIC published a White Book (volume 1), which established the economic justification for innovation policy. The document proposed

\footnotetext{
${ }^{11}$ The following discussion is partly based on interview with a former high-ranking official of the CNIC, Santiago, Chile, July 2012.
} 
selective interventions based on the promotion of clusters. The CNIC created then 11 thematic roundtables in areas like higher education and innovation culture to agree on the following steps to take. Composed by experts, government officials and some members of the private sector, the roundtables resulted in a shopping list of measures that informed the proposals of the White Book's second volume. ${ }^{12}$

The CNIC developed an ambitious strategy of cluster promotion and took some useful steps to accelerate economic dynamism. Nevertheless, its interventions shared at least three common problems with other industrial policy initiatives. First, the CNIC was primarily a technocratic project with weak support from the private sector and few mechanisms to force private sector cooperation. Its initial top-down and technocratic bias continued in subsequent years. When Eduardo Bitrán was named president of the Consejo in 2008, he promoted better integration between ministries and more support from different political parties. Yet he made no effort to embed the organisation within the private sector. The creation of more dynamic links between large firms and small and medium firms was never in the agenda either.

Second, the main goal of the CNIC was to increase the innovation capacity by supporting sectors that were globally dynamic and where Chile had comparative advantages. The aim was exclusively to accelerate GDP growth and the strategy did not pay any attention to the link between innovation, firm size and income distribution. Other industrial policies have shared a similar problem, providing insufficient support to small and medium firms. For example, CORFO's GIF lending programme-which does concentrate on small and medium firms-managed only $1.1 \%$ of the total portfolio of the Chilean financial system in 2006, well below Mexico's NAFIN (9.7\%) and Colombia's BANCOLDEX (5.3\%) (Agosin et al. 2010). In key sectors like forestry, which are controlled by a few large groups, "the lack of a competition policy, as well as comprehensive public policy promotion of economic transformation, has impeded the upgrading and/or entrance of small and medium sized firms" (Devlin and Moguillansky 2012: 6).

Third, the efforts of the CNIC have lacked continuity: after the election of President Piñera in 2010 the sectoral interventions based on cluster promotion were discontinued (Devlin and Moguillansky 2012). The new administration (2010-2014) discouraged the active promotion of structural change, focusing exclusively on the creation of an efficient business environment (Agosín and Grau 2013). The conservative government was also reluctant to use the government's purchasing power to support small and medium firms. ${ }^{13}$

President Piñera's decision and Chile's overall weak and inconsistent approach to industrial policy responds in large part to the preferences of the private sector. Business groups and business associations have maintained a critical approach to direct state intervention (Rodríguez Fisse and Thomas 2014). For example, a

\footnotetext{
${ }^{12}$ Volume 2 defined nine sectors to promote (including fishery, offshoring, wine and mining) based on those discussions as well as a report prepared by the Boston Consulting Group.

${ }^{13}$ Interview with former government official and expert on production policies, Santiago, July 2012.
} 
high-ranking official from the Confederation for Production and Commerce I interviewed argued that innovation policy mobilised a lot of resources but was quite inefficient. He also suggested that the private sector should drive innovation efforts and, when discussing strategic sectors, came back repeatedly to the central role of mining. ${ }^{14}$ This is not surprising: as previously discussed, the business elite's main interests are in mining, finance and non-tradable goods and services. Promoting new sectors is not their priority and could lead to the emergence of threatening competition.

\subsection{Trade Unions and the Influence of Labor}

Trade unions play a significant role in the (re)distribution of income, at least in OECD countries (Blau and Kahn 1996; Huber and Stephens 2001). They pressure median wages upward and often contribute to reduce the wage gap (see Panagides and Patrines 1994 for the Mexican case and a review of the literature in Torrés 2014). They can also influence the functional distribution between wages and profits and reduce top incomes. In the case of the USA, for example, Volscho and Kelly (2012) show that a 1 percentage point increase in union membership would result in a 0.4 percentage point reduction in the income share of the super-rich.

In Chile, as we mentioned before, trade unions were severely repressed after the 1973 coup. The main trade union confederation was outlawed and many of its leaders detained. All existing labour contract regulations were suspended and labour markets liberalised (Berg 2006). Unionisation rates plummeted: the share of union workers in the total labour force went from $33.7 \%$ in 1973 to just $9.8 \%$ in 1985 while union size halved (Donoso 2013a).

With the return to democracy in 1990, trade unions were free again to negotiate contracts and organise strikes, but they never recuperated its previous influence. The main trade union confederation was co-opted by successive Concertación administrations and played a secondary political role (Donoso 2013a). Unionisation rates stagnated and collective agreements remain sparingly used. In 2013 the percentage of workers under collective bargaining or under joint contract-a weaker type of agreement-was below $12 \%$, more than four percentage points lower than in $1990 .{ }^{15}$

A combination of political and economic factors explains the ongoing weakness of trade unions (Donoso 2013a; Leiva 2012; Winn 2004). On the political front, the

\footnotetext{
${ }^{14}$ Interview with a member of the Confederación de la Producción y del Comercio, Santiago, July 2012.

${ }^{15}$ The Labor Department only publishes data on new agreements signed every year. Each collective agreement can last between 2 and 4 years but data on the average length is not available (Departamento de Trabajo 2014). If all agreements lasted 2 years, only $8 \%$ of all workers would benefit in 2013. If all agreements lasted for 4 years, $15 \%$ of workers would be included. I have chosen as the best approximation the average of those two numbers (11.6\%). The data for 1990 comes from Leiva (2012).
} 
memory of the dictatorship and its terrible consequences contributed to the adoption of a moderate strategy. Union leaders were also reluctant to oppose governments led by anti-dictatorship colleagues. The dominance of liberal ideologies was also important. Successive Chilean administrations focused on growth promotion through free markets and trade liberalisation, fighting inequality exclusively through social policy (Palma 2011). As part of this policy approach, the government maintained "labour legislation that is one of the most restrictive on union bargaining power in the world" (Landerretche et al. 2013: 166). The business elite also opposed ferociously various attempts to reform labour laws, watering down proposals that were quite timid to start with (Sehnbruch 2006).

On the economic front, labour market deregulation and expansion of subcontracting arrangements constrain the opportunities for effective union organisation (Berg 2006). Structural heterogeneity - particularly the dominance of small, low-productivity firms - and the growing share of services - where unionisation is significantly harder than in manufacturing - have also been problematic. ${ }^{16}$

In the last decade, there have been some advances. Unionisation rates have recuperated slightly, going from $10.9 \%$ of the working population in 2000 to $11.9 \%$ in 2013 (Fig. 4). The size of trade unions has also expanded from a low of 72 workers

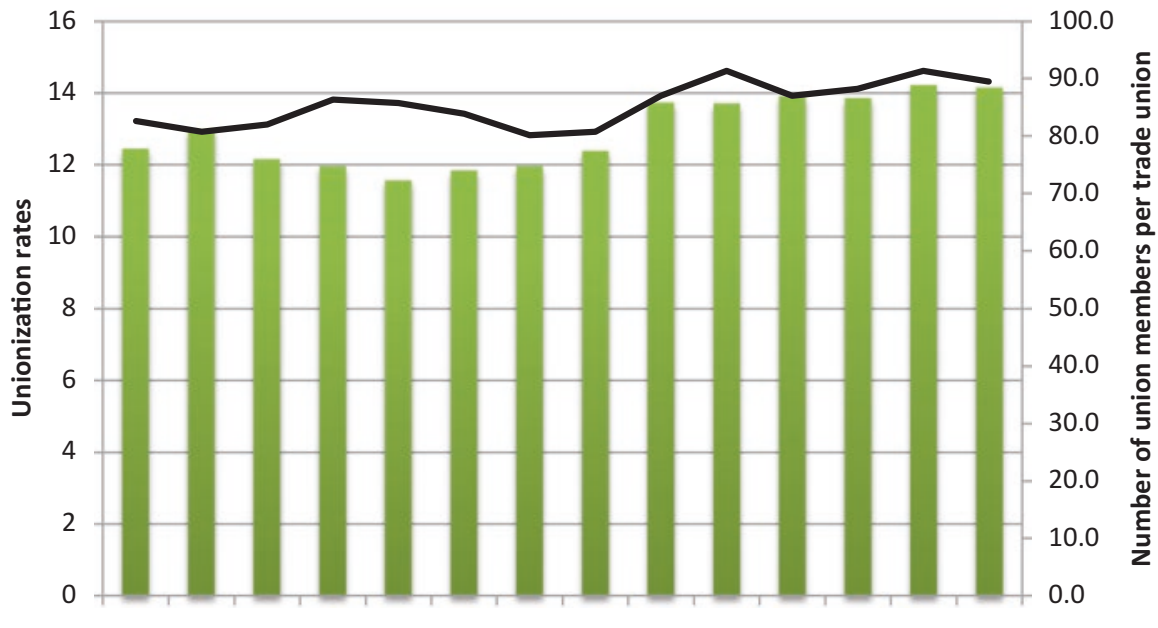

20002001200220032004200520062007200820092010201120122013

- • Total labor force _ Population allowed to unionized

Fig. 4 Unionisation rates and trade union size, 2000-2013. Source: Own elaboration with data from Departamento de Trabajo (2014). Note: The dots represent the ratio between the unionised population and all workers, while the line only considers those workers who can legally associate. It thus excludes public servants. The OECD statistics show a similar trend although with slightly higher values (e.g. unionisation rate in 2012 is 15.2)

\footnotetext{
${ }^{16}$ According to Landerretche et al. (2013) more than half of all large firms have unions compared to just $3 \%$ of small firms and $1 \%$ of microenterprises.
} 
per union in 2004 to 88 in 2013. The emergence of grass-roots unions with more direct links to the rank and file constitutes an even more significant change. Led by subcontracted workers, who demand equal treatment to those employed directly by companies, the new groups first appeared in the state-owned National Copper Corporation (Corporación Nacional del Cobre, CODELCO). ${ }^{17}$ The first organised protests took place in 2003 and led to the creation of the National Association of Subcontracted Workers (CNTC) (Hughes 2013). An indefinite strike in 2006 in several mines forced CODELCO to negotiate directly with the subcontracted workers and grant them a special bonus. The government also passed a Subcontracting Law in January 2007. The slow implementation of that law subsequently led to the intensification of the conflict between subcontracted workers and the state, strengthening the new labour movement in the process (Donoso 2013a). In recent years, grassroots unions have progressively expanded to private mining companies, forestry and salmon processing (Leiva 2012) and have opened new opportunities to developed countervailing social forces.

Nevertheless, these changes should not be exaggerated: trade unions are weak and have a limited influence on income concentration. Unionisation rates are still well below the highs of the early 1970s. Laws still discriminate against trade unions, which are not allowed to negotiate either at the business group or national levels. ${ }^{18}$ The impact of grass-roots unions on collective rights and state behaviour has also been smaller than initially expected (Donoso 2013a). New unions will only revitalise the labour movement if they can ally with traditional organisations and build more productive interactions with left-wing parties - something they have so far failed to do. Otherwise, their political influence and contribution to the erosion of top incomes in the long run will be limited.

\subsection{More Advances in Tax and Social Policies?}

While the Chilean Government has been reluctant to adopt an interventionist stand in production and the labour market, it has gradually implemented more active policies in the social realm. Since 2005, Chile has gradually moved "toward a more universal system of social protection, inspired by left commitments to social equity, justice and solidarity" (Huber et al. 2010: 82). The expansion of social spending has in turn created new conflicts over taxation and could gradually consolidate a broader redistributed cross-class coalition. Overall, the system has become more redistributive from a historical perspective: since 1990 the top quintile pay more in taxes than

\footnotetext{
${ }^{17}$ Subcontracting in the copper sector expanded rapidly in the 2000s. Between 1999 and 2004 the share of firms with subcontracted workers went from 37 to $63 \%$. In $201182 \%$ of the companies in the sector were subcontractors (Hughes 2013).

${ }^{18}$ The minimum wage has also increased less than in neighbouring countries: between 2003 and 2009 , the minimum wage increased by an annual average of $2.4 \%$ compared to $6.6 \%$ in Brazil and a double-digit growth in Uruguay (ILO 2010).
} 
receive in benefits (Arroyo Abad and Lindert, this volume) and the redistributive capacity of the state keeps improving.

The creation of basic health entitlements for the population at large through the Plan for Universal Access with Explicit Guarantees (Plan de Acceso Universal con Garantías Explícitas, Plan AUGE) has probably been the most significant of these pro-universal moves (Martínez Franzoni and Sánchez-Ancochea, 2014). The AUGE plan created a universal mandate for a list of services that every health insurer is obliged to provide within explicit timelines, thus stopping the practice of private providers offering plans that omitted key procedures such as reproductive healthcare for women (Ewig 2008). The plan introduced price limits on private insurance plans and created incentives to reduce age and gender discrimination (Ewig and Palmucci 2012). In addition to the AUGE bill (passed as Ley 19.996 of September 2004), three additional bills were introduced: two established more regulation over private providers and a third, the Sanitation Authority Law (Ley de Autoridad Sanitaria), gave hospitals greater autonomy.

Financial needs and electoral pressures explain why the government succeeded in passing a reform that favoured the poor and the middle class (Pribble 2013). Public health spending had increased steadily during the 1990s partly because the state covered the costs of services that the private insurance did not include. The Lagos administration (2000-2006) had to find new ways to control public spending while increasing the state's funding capacity simultaneously. At the same time, an expansionary reform had cross-class appeal as the middle class was increasingly using state services.

The ultimate impact of the reform was constraint by the influence of the elite. Private insurance companies operating often through right-wing political parties succeeded in limiting cross-subsidies between the private and public sector (Pribble 2013). During implementation, they also adopted pricing strategies that limited AUGE's positive impacts on gender and age inequalities (Ewig and Palmucci 2012).

Despite these problems, AUGE clearly contributed to move Chile's social policy into a universal path. The basket of required treatments has been expanded steadily based upon their cost-effectiveness in preventing death and disability (Ewig and Kay 2011). ${ }^{19}$ A draft bill currently discussed following recommendations from a public-private commission will likely establish a minimum, common insurance for public and private providers, create a common pull with all private contributions and establish a new fund for high-cost medicines in both systems (Oxford Analytica 2014). This process of unification will further enhance cross-class coalitions in support of further expansions of healthcare.

New pension benefits have also been important. The 2008 pension reform introduced a new redistributive benefit program, the Basic Solidarity Pension (Pensión Básica Solidaria). This pension can reach up to $\$ 160$ per month and involves a public subsidy to households earning up to $60 \%$ of the income scale. The reform

\footnotetext{
${ }^{19}$ The most recent changes added 9 new pathologies, increasing the total number to 80 . See, for example, http://www.supersalud.gob.cl/difusion/572/w3-article-8260.html (last accessed 23 November 2014).
} 
also included a bonus for each live birth that women have, therefore acknowledging time devoted to child birth and child-rearing (Ewig and Kay 2011).

While the pension reforms maintained private individual accounts as the core of the pension system, they opened the door for subsequent progressive changes in the system. Upon taking office for the second time in 2014, President Bachelet created a high-level commission to explore the sustainability of the pension system and the link between its various components. The most important proposal on the table is the creation of a state-led insurance company (a public AFP). If introduced, this reform would reduce the large commissions that the private AFPs charge and weaken private providers more generally.

The most evident display of cross-class coalition and middle-class "voice" has taken place in education. In recent years, secondary school and college students have repeatedly protested against the excessive costs of education and the lack of a high-quality, public education. ${ }^{20}$ In a first round of protests, in 2006 secondary school students (the so-called Pingüinos) succeeded in putting education reform in the agenda, even if they did not have much influence in the design of the subsequent legal framework (Donoso 2013b). More recent protests from college students placed the demand for free education at the centre of the agenda, and influenced the 2014 electoral campaign. This messier and less predictable policy process can be considered as an indication of an emerging politics of redistribution that is less complacent with the elite. In fact, according to Fairfield (2014: 16), "the 2011 and 2012 student protests ... dramatically expanded the scope of debate on progressive taxation".

This is welcome news for tax policy and a demonstration of the links between social policies and taxation politics in Chile. In the last two decades, the need to expand social policy in the context of fiscal discipline has created periodic pressures to expand revenues (Fairfield 2015; Pribble 2013). Increases focused primarily on the value-added tax, whose rate was raised as a result of the creation of AUGE and earlier education reforms (Pribble 2013). VAT increases, in turn, were used to demand progressive changes in income taxes in several instances including during the discussion of the 2001 Anti-Evasion Law (Fairfield 2014).

Successive tax reforms have contributed to a moderate expansion in the tax burden. Taxes as percentage of GDP grew from $17 \%$ in 1990 to $23 \%$ in 2007, decreasing more recently as a result of the global financial crisis and the end of the commodity boom (Fig. 5). More significantly for redistribution, income taxes have been behind this positive trend: their share in the total went from only $23 \%$ in 1990 to $46 \%$ in 2007 . The 2014 reform should further increase both total revenues in general and income taxes in particular, expanding the progressive capacity of the state.

Despite these improvements, the Chilean state still struggles to tax high-income groups. Fiscal loopholes, which benefit the elite disproportionally, represent an estimated $4 \%$ of GDP, more than in any other OECD country but Mexico (López 2011).

\footnotetext{
${ }^{20}$ In the late 2000 s, the public sector spent just $20 \%$ more than the private sector despite having to serve nine times more students (López 2011). The Chilean education system also has significant spatial inequalities and the costs of tertiary education remains high.
} 


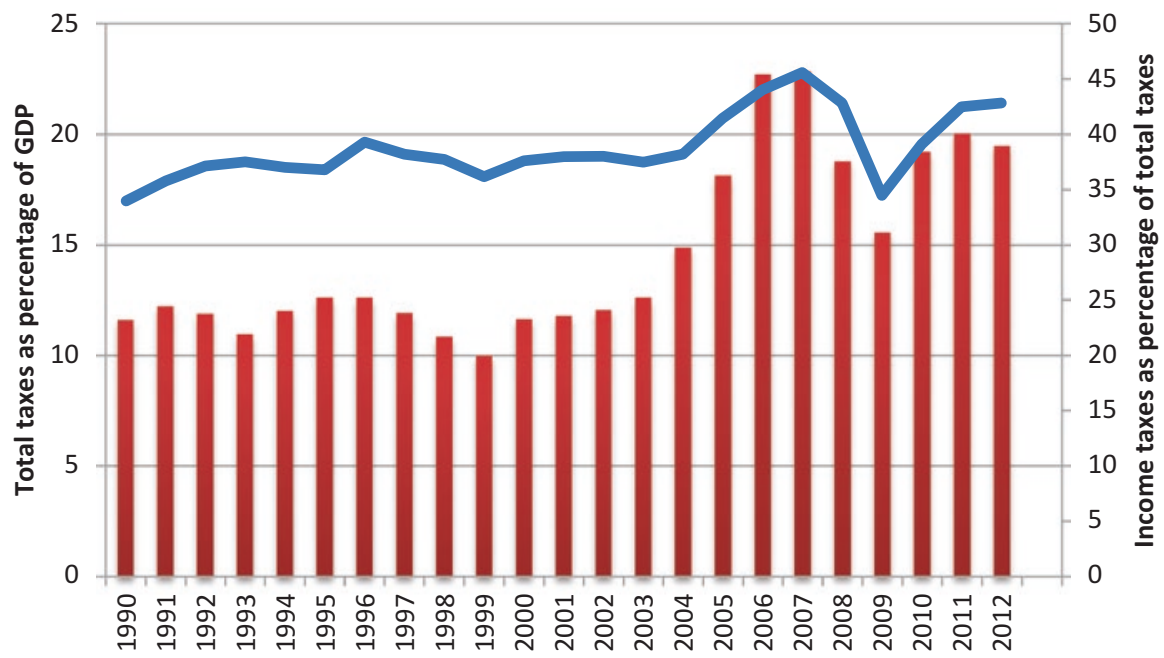

Income taxes (\% total) Total taxes

Source: own elaboration with OECD data

Fig. 5 Tax burden (\% GDP) and income taxes (\% total), 1990-2012. Source: Own elaboration with OECD data

Taxes on natural resource rents in sectors like aquaculture, fisheries and forestry remain low (López and Miller 2008) and the tax rates of the wealthy are significantly below other countries. The average effective tax rate for the richest $1 \%$ is around $16 \%$, compared to $24 \%$ in the USA and a higher level in other OCDE countries (Fairfield and Jorratt 2014).

These problems reflect the ability of the elite to water down various reform attempts. Thanks to its close ties to right-wing opposition parties and its resources to lobby the government, the business elite has succeeded in leaving the corporate tax and access to bank information outside of the policy agenda (Fairfield 2010). The business elite was also successful in watering down Bachelet's ambitious reform proposals in 2015. The results of future struggles over taxes and social policy will depend on the capacity of the emerging cross-class redistributive coalitions to confront this persistent elite power.

\section{Conclusion}

The recent literature on Latin America's performance (much of which is discussed in other chapters of this volume) has praised the reduction in inequality since the early 2000s (Cornia 2014; Gasparini and Lustig 2011; López-Calva and Lustig 2010). Yet how sustainable is this positive trend? Is Latin America truly in a new era? 
To answer these questions, we should consider how much the income share of the wealthy is changing and why. Given data limitations and the importance of politics, this requires a multidisciplinary approach that combines statistics with the study of policymaking and political trajectories.

This chapter adopted this approach to explore the case of Chile-one of the Latin American countries where inequality at the top is most striking. I collected a variety of evidences to show persistent concentration of income at the top. To understand this persistence and consider future trajectories, I studied changes in the structure of the economy, trade unions and the state's redistributive capacity. My analysis illuminates some contradictory trends. Economically, capital income and market concentration remain high with a few business groups controlling large segments of the economy. The state's capacity to make changes in production and reduce structural heterogeneity is persistently low. At the same time, however, social policy has become more redistributive and may be contributing towards the creation of new progressive cross-class coalitions. Higher social spending has also pushed taxation upwards - even if the elite is still paying well below its fair share. A positive scenario for the future would be one in which new social policies create new social expectations and demands, which, in turn, lead to higher taxes. Given the lack of the government's commitment to more radical measures, only in this indirect way will the income share of the rich decrease over the very long run.

Acknowledgements Research funded partly by CAF-Development Bank of Latin America and the Fell Fund at the University of Oxford. Special thanks to Giorgio Bocccardo for valuable research assistance and to Alan Angel, Luis Bertola, Juliana Martínez Franzoni, Javier Rodríbuez Weber and Jeffrey Williamson for comments on an earlier draft.

Open Access This chapter is distributed under the terms of the Creative Commons Attribution 4.0 International License (http://creativecommons.org/licenses/by/4.0/), which permits use, duplication, adaptation, distribution and reproduction in any medium or format, as long as you give appropriate credit to the original author(s) and the source, a link is provided to the Creative Commons license and indicate if changes were made.

The images or other third party material in this chapter are included in the work's Creative Commons license, unless indicated otherwise in the credit line; if such material is not included in the work's Creative Commons license and the respective action is not permitted by statutory regulation, users will need to obtain permission from the license holder to duplicate, adapt or reproduce the material.

\section{References}

Acemoglu, D., Johnson, S., \& Robinson, J. (2001). The colonial origins of comparative development. American Economic Review, 91(5), 1369-1401.

Acemoglu, D., \& Robinson, J. (2012). Why nations fail: The origins of power, prosperity and power. New York: Crown Business. 
Agosín, M., \& Grau, N. (2013). Industrial policy in Chile. unpublished manuscript, University of Chile (an earlier version of the paper was published as "Industrial Policy in Chile" IDB Working Papers no IDB-WP-170).

Agosin, M., Larrain, C., \& Grau, N. (2010). Industrial policy in Chile. Working Paper No. IDB-WP-170. Washington, DC: Inter-American Development Bank.

Alvarado, F., \& Londoño, J. (2012). High incomes and personal taxation in a developing economy: Colombia 1993-2010. CEQ Working Paper.

Amsden, A. (2001). The rise of "the rest": Challenges to the west from late-industrializing economies. New York, NY: Cambridge University Press.

Amsden, A., \& Di Caprio, A. (2012). Understanding the dynamics of elite behaviour in a development context. In A. Amsden, A. Di Caprio, \& J. Robinson (Eds.), The role of elites in economic development. Oxford: Oxford University Press.

Amsden, A., Di Caprio, A., \& Robinson, J. (Eds.). (2012). The role of elites in economic development. Oxford: Oxford University Press.

Atkinson, A., \& Piketty, T. (2010). Top incomes in global perspective. Oxford: Oxford University Press.

Berg, J. (2006). Miracle for whom? Chilean workers under free trade. London: Routledge.

Bertola, L. (2012). Institutions and the historical root of Latin American divergence. In J. A. Ocampo \& J. Ros (Eds.), Oxford handbook of Latin American economics. Oxford: Oxford University Press.

Bhattacherjee, D. (1987). Union-type effects on bargaining outcomes in Indian manufacturing. British Journal of Industrial Relations, 25(2), 247-266.

Blau, F., \& Kahn, L. (1996). International differences in male wage inequality: Institutions versus market forces. Journal of Political Economy, 104(4), 791-836.

Cardoso, C. F. S., \& Pérez Brignoli, H. (1979). Historia éconómica de América Latina. Barcelona: Critica.

Coatsworth, J. (2008). Inequality, institutions and economic growth in Latin America. Journal of Latin American Studies, 40, 545-569.

Cornia, A. (2010). Income distribution under Latin America's new left governments. Journal of Human Development and Capabilities, 11(1), 85-114.

Cornia, A. (Ed.). (2014). Falling inequality in Latin America: Policy lessons and changes. Oxford: Oxford University Press (WIDER Studies in Development Economics).

Departamento de Trabajo (2014). Compendio de Series Estadísticas 1990-2013. Santiago: Gobierno de Chile. Retrieved May 10, 2015 from http://www.dt.gob.cl/documentacion/1612/ w3-propertyvalue-22777.html.

Devlin, R., \& Moguillansky, G. (2012). What's new in the new industrial policy in Latin America? World Bank Policy Research Working Paper 6191, Washington.

Donoso, S. (2013a). Reconstructing collective action in the Neoliberal Era: The emergence and political impact of social movements in Chile since 1990. Thesis submitted in partial fulfilment of the requirements for the Degree of Doctor of Philosophy in Development Studies, University of Oxford.

Donoso, S. (2013b). Dynamics of change in Chile: Explaining the emergence of the 2006 Pingüino movement. Journal of Latin American Studies, 45(1), 1-29.

Engerman, S., \& Sokoloff, K. (1997). Factor endowments, institutions and differential paths of growth among new world economies: A view from economic historians of the United States. In S. Haber (Ed.), How Latin America fell behind: Essays on the economic histories of Brazil and Mexico (pp. 1800-1914). Stanford, CA: Stanford University Press.

Ewig, C. (2008). Reproduction, re-reform, and the reconfigured state: Feminists and neoliberal health reforms in Chile. In I. Bakker \& R. Silvey (Eds.), Beyond states and markets: The challenges of social reproduction (pp. 143-158). New York: Routledge.

Ewig, C., \& Kay, S. (2011). Post-retrenchment politics: Policy feedbacks in health and pension reforms in Chile. Latin American Politics and Society, 53(4), 67-99.

Ewig, C., \& Palmucci, G. (2012). Inequality and the politics of social policy implementation: Gender, age and Chile's 2004 health reforms. World Development, 40(12), 2490-2504. 
Fairfield, T. (2010). Business power and tax reform: Taxing income and profits in Chile and Argentina. Latin American Politics and Society, 52(2), 37-71.

Fairfield, T. (2014). The political economy of progressive tax reform in Chile. Washington: Woodrow Wilson Center Update on the Americas.

Fairfield, T. (2015). Private wealth and public revenue in Latin America. Business power and tax politics. Cambridge, UK: Cambridge University Press.

Fairfield, T., \& Jorratt, M. (2014). Top income shares, business profits and effective tax rates in contemporary Chile. ICTD Working Paper, 17. Brighton: Institute of Development Studies.

Fazio, H. (1999, December) La transnacionalización de la economía chilena. Mapa de la extrema riqueza al año 2000. Santiago: LOM Ediciones.

Fernández Jilberto, A., \& Hogenboom, B. (2007). Big business and economic development. Conglomerates and Economic groups in developing countreis and transition economies under globalization. London/New York, NY: Routledge.

Friedman, J., \& Hofman, A. (2013). Inequality and the top of the income distribution in Chile 1990-2012: Questioning the consensus. Retrieved from http://papers.ssrn.com/sol3/papers. cfm?abstract_id $=2242259$.

Furtado, C. (1974). La economía Latinoamericana desde la Conquista Ibérica hasta la Revolución Cubana. Mexico: Siglo XXI.

Gasparini, L., Galiani, S., Cruces, G., \& Acosta, P. (2011). Educational upgrading and returns to skills in Latin America: Evidence from a supply-demand framework, 1990-2010. IZA Discussion Paper 6244.

Gasparini, L., \& Lustig, N. (2011). The rise and fall of income inequality in Latin America. ECINEQ Working paper 2011-213.

Gindling, T. H., \& Trejos, J. D. (2013). The distribution of income in Central America. In D. Sánchez-Ancochea \& S. Martí (Eds.), Handbook of Central American governance. London: Routledge.

Gogna, M. (Ed.). (2004). Las reformas en el sector salud en la Argentina y Chile. Oportunidades y obstáculos para la promoción de la salud sexual y reproductiva. Buenos Aires: CEDES.

Guerreiro, M. (2012). The labour share of income around the world. Evidence from a panel dataset. Development Economics and Public Policy Working Paper Series, No. 32/2012.

Huber, E., Pribble, J., \& Stephens, J. (2010). The Chilean left in power: Achievements, failures and omissions. In K. Weyland, R. Madrid, \& W. Hunter (Eds.), Leftist governments in Latin America: Successes and shortcomings. New York, NY: Cambridge University Press.

Huber, E., \& Stephens, J. (2001). Development and crisis of the welfare state: Parties and policies in global markets. Chicago, IL: University of Chicago Press.

Huber, E., \& Stephens, J. (2012). Democracy and the left. Social policy and inequality in Latin America. Chicago, IL: Chicago University Press.

Hughes, M. (2013). Re-estructuración capitalista: precariedad laboral y resistencia. La protesta de los mineros del cobre en Chile. Horizontes Antropológicos, 19(39), 99-124.

Infante, R., \& Sunkel, O. (2009). Chile: Towards inclusive growth. CEPAL Review, 97, 133-152.

International Labor Organization (ILO). (2010). Panorama Laboral 2010, América Latina. Lima: International Labor Organization.

Kahn, S. (2012). The sociology of elites. Annual Review of Sociology, 38, 361-377.

Karabarbounis, L., \& Neiman, B. (2013). The global decline of the labor share. NBER Working Paper 19136.

Landerretche, O., Lillo, N., \& Puente, E. (2013). The union effect on wages in Chile: A two-stage. Labour, 27(2), 164-191.

Leiva, F. (2012). Flexible workers and gender in Chile: Contending strategies for confronting the crisis of labor. Latin American Perspectives, 39(4), 102-128.

López, R. (2011). Fiscal policy in Chile: Promoting faustian growth? Working Paper 11-01. College Park: The University of Maryland.

López, R., Figueroa, E., \& Gutiérrez, P. (2013). La Parte del León: Nuevas Estimaciones de la Participación de los Súper Ricos en el Ingreso de Chile. Working Paper 379, Facultad Economía y Negocios, Universidad de Chile, Departamento de Economía. 
López, R., \& Miller, S. (2008). Chile: The unbearable burden of inequality. World Development, 36(12), 2679-2695.

López-Calva, L., \& Lustig, N. (Eds.). (2010). Declining inequality in Latin America. A decade of progress? Washington, DC: Brookings Institution Press.

Lynch, M. (2006). World Wealth Report, 2006. Merryll Lynch and Capgemini.

Martínez Franzoni, J., \& Sánchez-Ancochea, D. (2013). Good jobs and social services: How Costa Rica achieved the elusive double incorporation. Basingstoke: Palgrave McMillan.

Martínez Franzoni, J., \& Sánchez-Ancochea, D. (2014). The double challenge of market and social incorporation progress and bottlenecks in Latin America. Development Policy Review, 32(3), 275-298.

Martínez Franzoni, J., \& Sánchez-Ancochea, D. (2016). The quest for universal social policy in the South: Actors, ideas and architectures. Cambridge: Cambridge University Press.

Medeiros, M., Souza, P., \& Castro, F. (2014). O Topo da Distribuição de Renda no Brasil: primeiras estimativas com dados tributários e comparação com pesquisas domiciliares. Retrieved from SSRN: http://ssrn.com/abstract=2479685.

Mesa-Lago, C. (1978). Social security in Latin America: Pressure groups, stratification and inequality. Pittsburgh, PE: University of Pittsburgh Press.

Oxford Analytica (2014). Chile private healthcare reforms signal wider plans. Oxford Analytica Daily Brief. 19 November.

Palma, G. (2011). Homogeneous middles vs. heterogeneous tails, and the end of the 'Inverted-U': It's all about the share of the rich. Development and Change, 42(1), 87-153.

Panagides, A., \& Patrines, H. (1994). Union-non-union wage differentials in the developing world: A case study of Mexico. Policy Research Working Paper \# 1269.

Piketty, T. (2014). Capital in the 21st century. Cambridge, MA: Harvard University Press.

Piketty, T., \& Saez, E. (2006). The evolution of top incomes: A historical and international perspective. American Economic Review, 96(2), 200-205.

Pinto, A. (1970). Desarrollo Económico y relaciones sociales. In CESO: Chile, hoy. Santiago: Siglo XXI Editores.

Pribble, J. (2013). Welfare and party politics in Latin America. Cambridge: Cambridge University Press.

Ricardo, F.-D. (2010). Economic reforms in Chile: From dictatorship to democracy (2nd ed.). Basingstoke: Palgrave McMillan.

Riesco, M. (2007). Se derrumba un mito: Chile reforma sus privatizados sistemas de educación y salud. Santiago: Centro de Estudios Nacionales de Desarrollo Alternativo CENDA.

Robinson, J. (2012). Elites and institutional perspective. In A. Amsden, A. Di Caprio, \& J. Robinson (Eds.), The role of elites in economic development. Oxford: Oxford University Press.

Rodríguez Fisse, H., \& Thomas, C. (2014). The Chilean big business lobby: A long-standing and major influence on public policy. Journal of Public Affairs, 14(3-4), 310-330.

Rodríguez Weber, J. (2014). La Economía Política de la Desigualdad de Ingreso en Chile, 1850-2009. Doctoral Thesis in Economic History, Universidad de la República, Montevideo (Uruguay).

Ruiz, C., \& Boccardo, G. (2010). Problemas sociales de la Concentración Económica (vistos desde la crisis). Revista Análisis del año 2009. Revista del Departamento de Sociología.

Sanchez-Ancochea, D. (2009). Public budgets and income inequality in Latin America: A comparative perspective. In D. Sánchez-Ancochea \& I. Morgan (Eds.), The political economy of the public budget in the Americas. London: Institute for the Study of the Americas.

Sandbrok, R., Edelman, M., Heller, P., \& Teichman, J. (2007). Social democracy in the global periphery: Origins, challenges, prospects. Cambridge: Cambridge University Press.

Schneider, B. (2008). Economic liberalization and corporate governance: The resilience of economic groups in Latin America. Comparative Politics, 40(4), 379-397.

Schneider, B. (2013). Hierarchical capitalism in Latin America: Business, labor, and the challenges of equitable development. New York, NY: Cambridge University Press.

Segura-Ubiergo, A. (2007). The political economy of the welfare state in Latin America: globalization, democracy, and development. Cambridge: Cambridge University Press. 
Sehnbruch, K. (2006). The Chilean labor market. A key to understanding Latin American labor markets. New York: Palgrave Macmillan.

Silva, E. (1996). The state and capital in Chile: Business elites, technocrats, and market economics. New York, NY: Westview Press.

Solimano, A. (2009). Concentración económica y heterogeneidad productiva en Chile. documento preparado para la Fundación Chile XXI.

Torche, F. (2005). Unequal but fluid social mobility in Chile in comparative perspective. American Sociological Review, 70(3), 422-450.

Torrés, N. (2014). The role of labor unions and collective bargaining in labor markets: Correction of market imbalances and redistribution of wealth. Thesis submitted at the Central European University, Budapest.

Velasco, A., \& Huneeus, C. (2011). Contra la desigualdad: el empleo es la clave. Santiago: Editorial Debate.

Volscho, T., \& Kelly, N. (2012). The rise of the SuperRich: Power resources, taxes, financial markets, and the dynamics of the top 1 percent, 1949-2008. American Sociological Review, 77(5), 679-699.

Williamson, J. (2010). Five centuries of Latin American income inequality. Revista de Historia Económica, 28(2), 227-252.

Winn, P. (2004). Victims of the Chilean Miracle: Workers and Neoliberalism in the Pinochet Era, 1973-2002. Durham, NC: Duke University Press.

World Bank (2003) Inequality in Latin America. Breaking with History? Washington, DC: World Bank.

Yotopoulos, P. (1989). The (rip) tide of privatization: Lessons from Chile. World Development, 17(5), 683-702.

Diego Sánchez-Ancochea is the Director of the Latin American Centre and Associate Professor of Political Economy at the University of Oxford. His research focuses on income inequality and social policy. Together with Professor Juliana Martínez Franzoni, he is the author of The Quest for Universal Social Policy in the South: Actors, Ideas and Architectures (Cambridge University Press 2016) as well as other manuscripts and papers in international journals. He is also co-editor of the Journal of Latin American Studies. 